\title{
Relationship between GDP, Foreign Direct Investment and Export Volume: Evidence from Indonesia
}

\author{
Iman Naufal Mahadika, Salih Kalayci and Nihal Altun
}

\begin{abstract}
Using time-series and co-integration test from 1981 to 2013, this manuscript examines the long-run relations between FDI, GDP and export volume of Indonesia. The impact of Indonesian export volume and FDI on Indonesian GDP were measured in this article, it has been found that export volume and FDI have significant influence on economic growth of Indonesia. In addition, according to Johansen cointegration test, there is long-run relationship between GDP, FDI and export volume of Indonesia. The empirical findings are consistent with other academic articles.
\end{abstract}

Index Terms-International economics, international trade, GDP, FDI, export volume.

\section{INTRODUCTION}

As one of the main economic power in South East Asia, Indonesia is facing a stable economic growth through this decade which lies between $4 \%-6 \%$. Today, Indonesia is the world's fourth most populous nation, the world's 10th largest economy in terms of purchasing power parity (PPP). Badan Pusat Statistic (2016), Indonesia has a trade surplas because of its rapid export of goods such as coal briquettes, palm oil, petroleum gas, crude petroleum and rubber which are the main exports of Indonesia. According to Central Bureau of Statistics in Indonesia, in 2016 Indonesia has a monthly average of 1 billion US\$ trade surplus [1].

Indonesia is also an emerging market economies of the world with massive consumption rate so that it attracts foreign investors to invest in Indonesia. The presence of Indonesia in some international trading organizations such as G-20 (Group of twenty) and ASEAN (Association of Southeast Asian Nations) gives a better economic prospect of Indonesia which is good for future investment. About the Foreign Direct investment (FDI), the impact of FDI (Foreign Direct Investment) on economic growth has been argued considerably in the development and economic growth literature for many years. The inflows of FDI have a potential for increasing the rate of economic growth in a country. These inflows of physical capital resulting from FDI could also increase the rate of economic growth. The

FDI inflows into a country are also often linked with the economic prosperity issue. FDI now plays an important role in the internationalization of business. Profound changes have taken place both in terms of size, scope and methods of FDI in the last decade. These changes occur due to technology, easing restrictions on foreign investment and acquisitions in many countries, and the deregulation and

Manuscript received January 3, 2017; revised February 28, 2017.

Salih Kalayci is with Bursa Technical University, Turkey (e-mail: salih.kalayci@btu.edu.tr). privatization of many industries. The development of information technology systems and cheap global communication enables management of foreign investments much more easily.

Meanwhile the FDI in Indonesia, the Foreign Investment Act (1/1967) issued to attract foreign investment to build the national economy. Investment Coordinating Board (BKPM) is the authority to give approval for all FDI in Indonesia. Since 2010, FDI in Indonesia showed a rapid increase. Since then, Indonesia started to go and perch on the radar screen of foreign companies. The attractiveness of Indonesia as the market began to attract foreign companies to invest in Indonesia. The evidence is when Indonesia was able to face the global crisis of 2008-2009 by recording a positive growth of 4.6 percent in 2009. Only Indonesia, China and India recorded positive growth during the global financial crisis.

This paper attempts to assess the relationship between GDP of Indonesia, Foreign Direct Investment and Export Volume. Also we wanted to test which variable gives more impact on the GDP of Indonesia, whether it is the FDI or the export volume.

\section{LITERATURE REVIEW}

According to Hsiao (2006) there is long term relationship between GDP, FDI and Export volume. The findings of them are totally consistent with results of Johansen cointegration test [2]. According to Choong, Yusop and Soo (2004) the presence of FDI inflows creates a positive technological diffusion in the long run only if the evolution of the domestic financial system has achieved a certain minimum level [3]. They investigate the patterns of foreign direct investment (FDI) and economic growths are investigated among select developed and East Asian countries. They added that their study provides fresh ability to absorb the advantages inflows is mainly dependent on the host country, notably with regard sector development. According to Johnson (2006) FDI inflows have a positive effect on host country economic growth for developing but not for developed economies. Also the domestic investments have a positive effect on economic growth both in developed and developing economies.

He assumed that the direction of causality goes from inflows of FDI to host country economic growth. However, economic growth could itself cause an increase in FDI inflows. Economic growth increases the size of the host country market and strengthens the incentives for market seeking FDI [4]. According to Carkovic and Levine (2002) FDI inflows do not exert an independent influence on economic growth. Thus, while sound economic policies 
may spur both growth and FDI, the results are inconsistent with the view the FDI exerts a positive impact on growth that is independent of other growth determinants [5]. According to Helpman, Melitz and Yeaple (2003), They predicts that foreign markets are served more by exports relative to FDI sales when trade frictions are lower or economies of scale are higher. To these factors our model adds a role for the within-sectoral heterogeneity of the productivity levels of firms, which induces a size distribution of firms that also affects exports versus FDI sales. Using data on exports versus FDI sales of U.S. firms in 38 countries and 52 industries, they estimated the effects of trade frictions, economies of scale and within-industry dispersion of firm size on exports versus FDI sales. They show a robust cross-sectorial relationship between the degree of dispersion in firm size and the tendency of firms to substitute FDI sales for exports. The size of this effect is of the same order of magnitude as trade frictions [6].

\section{Methodology AND DAta AnAlysis}

According to the results of multivariate regression model of three variables at Table I, the effect of export volume and FDI have huge significance on GDP which is consistent with Yao's findings [7]. There is no autocorrelation problem because according to Fig. 1 residuals distributed randomly.

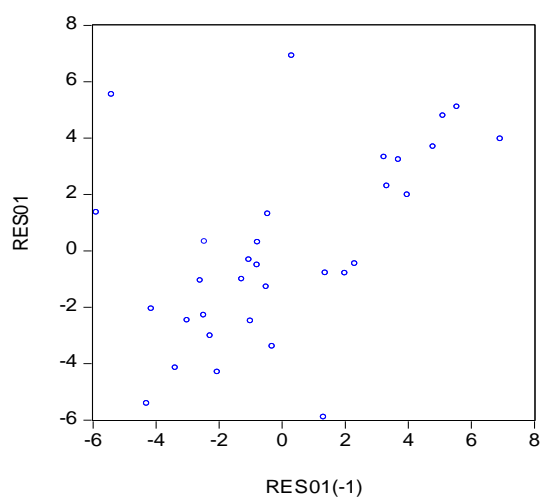

Fig. 1. Residual graph.

TABLE I: THE RESUlts OF MULTIVARIATE REgRESSION ANALYSIS Dependent Variable: GDP

Method: Least Squares

Sample: 19812013

Included observations: 33

\begin{tabular}{|lrllr|}
\hline \hline \multicolumn{1}{c}{ Variable } & Coefficient & Std. Error & t-Statistic & Prob. \\
\hline \hline \multicolumn{1}{c}{ EXP_VLM } & 2.067799 & 0.762158 & 2.713084 & 0.0109 \\
$\quad$ FDI & 2.146825 & 0.438638 & 4.894296 & 0.0000 \\
C & -59.13066 & 15.36725 & -3.847838 & 0.0006 \\
\hline \hline R-squared & 0.6590 & M dependent var & 34.169 \\
Adjusted R-squared & 0.6363 & S.D.dependentvar & 5.6296 \\
S.E. of regression & 3.3949 & Akaike info crt & 5.3689 \\
Sum squared resid & 345.77 & Schwarz criterion & 5.5050 \\
F-statistic & 28.995 & Durbin-Wtsstat & 1.9924 \\
Prob(F-statistic) & 0.0000 & & \\
\hline
\end{tabular}

According to the Augmented Dickey Fuller (ADF) test results at Table II, Table III and Table IV above the data are not stationary. Converting the data from non-stationary I (0) to stationary I (1), (Table V, VI and VII) the series have been transferred in the Johansen co-integration test. The results demonstrate that there is a long-term relation between FDI, Export Volume and GDP. According to Table VIII below, there is a long-term relationship between the variables of FDI, Export Volume and GDP.

TABLE II: ADF TEST OF GDP (BEFORE CONVERTING THE DATA FROM NON-STATIONARY TO STATIONARY)

\begin{tabular}{|c|c|c|c|}
\hline \multicolumn{4}{|c|}{$\begin{array}{l}\text { Null Hypothesis: GDP has a unit root } \\
\text { Exogenous: Constant } \\
\text { Lag Length: } 0 \text { (Automatic - based on SIC, maxlag=8) }\end{array}$} \\
\hline & & $\mathrm{t}-$ Statistic & Prob.* \\
\hline \multicolumn{2}{|c|}{$\begin{array}{l}\text { Augmented Dickey-Fuller test } \\
\text { statistic }\end{array}$} & -2.265010 & 0.1889 \\
\hline \multirow[t]{3}{*}{ Test critical values: } & $1 \%$ level & -3.653730 & \\
\hline & $5 \%$ level & -2.957110 & \\
\hline & $10 \%$ level & -2.617434 & \\
\hline
\end{tabular}

TABLE III: ADF TEST OF EXPORT VOLUME (BEFORE CONVERTING THE DATA FROM NON-STATIONARY TO STATIONARY)

Null Hypothesis: EXP_VLM has a unit root

Exogenous: Constant

Lag Length: 0 (Automatic - based on SIC, maxlag=8)

\begin{tabular}{|lccc|}
\hline \hline & t-Statistic & Prob.* \\
\hline \hline & & \\
Augmented Dickey-Fuller test statistic & -1.787593 & 0.3796 \\
\hline Test critical values: & $1 \%$ level & -3.653730 & \\
& $5 \%$ level & -2.957110 & \\
& $10 \%$ level & -2.617434 & \\
\hline \hline \multirow{3}{*}{ *MacKinnon (1996) one-sided p-values. } \\
\hline
\end{tabular}

TABLE IV: ADF TEST OF FDI (BEFORE CONVERTING THE DATA FROM NON-STATIONARY TO STATIONARY)

Null Hypothesis: FDI has a unit root

Exogenous: Constant

Lag Length: 0 (Automatic - based on SIC, maxlag=8)

\begin{tabular}{|c|c|c|}
\hline & t-Statistic & Prob.* \\
\hline $\begin{array}{l}\text { Augmented Dickey-Fuller test } \\
\text { statistic }\end{array}$ & -1.934750 & 0.3129 \\
\hline $\begin{array}{l}1 \% \text { level } \\
5 \% \text { level } \\
10 \% \text { level }\end{array}$ & $\begin{array}{l}-3.653730 \\
-2.957110 \\
-2.617434\end{array}$ & \\
\hline
\end{tabular}

TABLE V: ADF TEST OF GDP (AFTER CONVERTING THE DATA FROM NON-STATIONARY TO STATIONARY)

Null Hypothesis: GDP1 has a unit root

Exogenous: Constant

Lag Length: 0 (Automatic - based on SIC, maxlag=7)

\begin{tabular}{|lccc|}
\hline \hline & t-Statistic & Prob. ${ }^{*}$ \\
\hline \hline Augmented Dickey-Fuller test statistic & -8.406736 & 0.0000 \\
\hline Test critical values: & $1 \%$ level & -3.661661 & \\
& $5 \%$ level & -2.960411 & \\
& $10 \%$ level & -2.619160 & \\
\hline \hline & & \\
*MacKinnon (1996) one-sided p-values. & \\
\hline
\end{tabular}


demonstrated that majority of the fundamental scientific and technical journals were adapted to industry and implemented for export. In order to have more innovative export based on economic growth and sustainable long-term relation among China's economic growth and scientific, journal rates [8].

Johnson (2006) demonstrated that FDI inflows have a positive impact on host country GDP for enhancing but not for developed economies. The domestic investments have a positive influence on GDP both in developed and developing economies as well [4]. There are kinds of variables that affects both GDP and export volume. Kalayci and Yazici (2016) indicate that there is a long term relationship between GDP, export volume and civil aviation. Depending on that fact, they also specifies the growth of the USA's GDP contributed to the R\&D budged and due to that circumstances, the government invest more in the transportation infrastructure [9].

\section{REFERENCES}

[1] Badan Pusat Statistik. (2016). Statistics Indonesia. [Online]. Available: https://www.bps.go.id/

[2] F. S. T Hsiao and M. C. W. Hsiao, "FDI, exports, and GDP in East and Southeast Asia - Panel data versus time-series causality analyses," Journal of Asian Economics, vol. 17, no. 6 pp. 1082-1106, 2006.

[3] C.-K. Choong, Y. Zulkornain, and S.-C. Soo, "Foreign direct investment, economic growth, and financial sector development: A comparative analysis," ASEAN Economic Bulletin, pp. 278-289, 2004.

[4] J. Andreas et al., "The effects of FDI inflows on host country economic growth," The Royal Institute of technology. Centre of Excellence for studies in Science and Innovation, 2006.

[5] M. V. Carkovic and R. Levine, "Does foreign direct investment accelerate economic growth?" U of Minnesota Department of Finance Working Paper, 2002.

[6] E. Helpman, M. J. Melitz, and S. R. Yeaple, "Export versus FDI," National Bureau of Economic Research, no. 9439, pp. 1-46, 2003.

[7] S. Yao, "On economic growth, FDI and exports in China," Applied Economics, vol. 38, no. 3, pp. 339-351, 2006.
[8] H. Cetin, "The Short Term and Long Term Relationship between China's Fundamental, Scientific Journal Rates and Gross Domestic Product Sustainability," International Journal of Business and Management, vol. 8, no. 18, pp. 140-148, 2013.

[9] S. Kalayci and S. Yazici, "The Impact of export volume and GDP on USA's Civil Aviation in between 1980-2012," International Journal of Economics and Finance, vol. 8, no. 1, pp. 229-235, 2016.

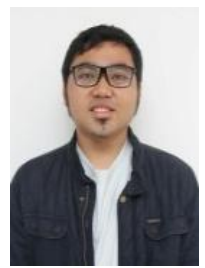

Iman Naufal Mahadika was born in Surabaya Indonesia. He is studying at Bursa Technical University majoring

Banking and Finance. He has been interested in banking, marketing and international trade.

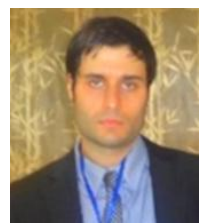

Salih Kalayci received his bachelor degree in international finance at Eastern Mediterranean University, Turkish Republic of Northern Cyprus (TRNC), the master of science degree in international business at Coventry University, United Kingdom (UK) and the $\mathrm{PhD}$ degree in business administration at Beykent University, Turkey. He is one of the founders of the Department of International Trade and Logistics at Bursa Technical University. Besides, $\mathrm{He}$ is also one of the founders of IBESRA (International Business Economics Social Sciences Research Association) Conference Organization. He is chair of International Trade department of Bursa Technical University nowadays.

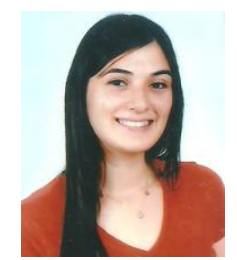

Nihal Altun graduated from Afyon Kocatepe University international trade and financing department. And also she is doing master's degree in international trade and finance at Celal Bayar University. 